\title{
Library Management Information System Using RFID and QR Code
}

\author{
Authors: I Gede Sujana Eka Putra', Tirta Mahayana², Agung \\ Wicaksono ${ }^{3}$
}

\author{
Affiliation: STMIK STIKOM Indonesia ${ }^{1}$, STMIK STIKOM Indonesia ${ }^{2}$, STMIK STIKOM \\ Indonesia $^{3}$
}

E-mail: sujanaekaputra@stiki-indonesia.ac.id ${ }^{1}$, dedetirtamahayana@gmail.com ${ }^{2}$,wicaksonomm1@gmail.com ${ }^{3}$

DOI: 10.26821/IJSHRE.9.8.2021.9701

\section{ABSTRACT}

RFID (Radio Frequency Identification) is a compact wireless technology which has been developed in the commercial world and one of them has implemented in library management system. RFID apply automation in example inventory control in identifying books in the library. RFID technology is widely used to help problems relating to the indexing of an object such as the identification of books on library, identification of membership or tracking for recording books. In terms of identifying an object, the library has implemented a process book identification using magnetic-based smartcards for self-service purposes. The library to manage books circulations, requires technology that is capable of identify objects simultaneously without direct contact required. Various problems that faced by libraries, including the lack of guarantees for the safety of books in the library, human resources library services have not optimal yet, book information availability accuracy. Based on that problem, this research conducts development of library management information system using automatic identifier utilizes RFID and QR Code technology. Each member information stored in $N F C$ card and each book information stored in $Q R$ Code label. Transaction of book loan and book return are done by tapping the NFC card and scanning QR Code label of each books. Testing the system by tapping an NFC Card (RFID) on a NFC Card reader/writer, the maximum distance is up to $7 \mathrm{~cm}$ can read NFC Card, while testing using $Q R$ Code label, it could be read at maximum distance
\end{abstract}

$40 \mathrm{~cm}$. Automatic identifier provides accurate information, improve library services and provide added value for library.

Keywords: Library; Automatic Identifier; QR Code; RFID; Inventory Control.

\section{INTRODUCTION}

RFID (radio frequency identification) is a technology that combines the functions of the coupling electromagnetic or electrostatic in the radio frequency portion of the electromagnetic spectrum, to identify an object [1]. With the development of information technology that supports the process of business, it requires system that make it easier for users to make transactions, for example, internet online payments, smart cards, radio frequency identification (RFID), mobile payments, financial technology and others. In everyday life, transactions such as payments are still using the manual method by using paper money and coins (cash) and now cashless transactions have begun a mechanism for exchanging transaction information digitally, which can improve accuracy and security the transaction itself. Near Field Communication is the development of radio technology frequency identification (RFID) which is used to communicate data using radio frequencies, where the media card can be stored data or data can be read using an NFC reader device. NFC can be used for digital transactions such as being able to transfer data quickly, make purchase transactions without the need to use unnecessary credit or debit 
Volume 9 Issue 8 August 2021

cards go through a very complicated activation process [2]. RFID consists of active and passive RFID. Active RFID labels have a strong signal and can transmit data over long distances. Passive RFID labels rely on an RFID reader to transmit data with short scanning distances, and lower production costs [11]. This research aims to implement the mechanism of borrowing and return of books in a practical way using RFID cards and QR Code labels. RFID card can have used to record visitor data, and transaction of book load or returning book is recorded by scanning QR Code labels. The urgency of research through the use of RFID technology is expected to make the process borrowing and returning books is more practical, supporting information on more accurate, improve library services for students and visitors and provide value add to the library in the efficiency and practicality of service.

\section{RELATED WORK}

Several previous studies conducted are as follows: research from [3] developed a lecturer attendance information system to record lecturer attendance using radio frequency identification technology by implementing Near Field Communication Card. Application to record lecturer attendance data during lectures, by tapping NFC card to the NFC reader/writer. The implementation of NFC cards is more practical for lecturers in conducting lecture attendance and NFC cards can be scanned at a maximum distance of up to $7 \mathrm{~cm}$ with a card reading angle to the reader device with a range of 00 to 300. Previous study from [4] implemented RFID in the patient medical record queuing system in hospitals, aimed at reducing patient queuing time when processing medical records at outpatient registration at the hospital, RFID was used for unique patient codes. This unique code will display patient data automatically so that it does not require time to search for patient files which can increase patient queue time. Another study from [5] examined the design of lecture attendance applications using NFC technology, an effort to facilitate the student attendance process, was carried out by using Android-based NFC. NFC technology on smartphones can detect the NFC chip on the card for the card owner identification process, students simply touch their identity card to the NFC tag detector and the system will input attendance automatically and connect to academic information systems. Previous study from [2] examined the application of the role and use of near field communication (NFC) technology to teaching and learning activities in universities, to provide convenience in the teaching and learning process for students and lecturers in providing lecture material even though the internet network is down. (off). In general, the presence of lecturer's attendance is recorded on manual form sheets, or through campus web applications that are accessed on computers in class, but sometimes problems on computer network access, so that attendance could not be done via web application. To overcome this, an NFC card is implemented where during lectures the lecturer taps the card on the provided NFC reader, and the lecturer's attendance data is recorded on the academic attendance information system. The data stored in the NFC card can be encrypted so that it is safe and not easy to be duplicated by others. Another study from [6] regarding the design of radio frequency identification (RFID) for the attendance system based on the ATmega 8535 microcontroller to read employee attendance information in the form of an attendance application to store and make employee attendance reports. The tag reading by the RFID reader must be at a maximum distance of $<=4 \mathrm{~cm}$ which has a $100 \%$ tag reading success rate. The time lag between reading the first tag and the second tag by the RFID reader must be more than 2 seconds for the tag to be read. Research from [7] developed a library application using smartcard RFID (Radio Frequency Identification). The increasing or increasing collection of library materials at the Regional Library and Archives Agency of South Kalimantan Province, the need for information on library materials increases, the limitations of library service officers are a problem in library management. The library information system starts from member data collection, book data collection, book borrowing, book return, library free letter giving and making reports including member data reports, book data reports, book borrowing reports, book return reports and fine receipt reports. This library application can maximize library services and minimize errors in data processing. Previous research from [9] regarding the application of RFID technology in filling out library visit data, connects an Arduinobased RFID reader with database reading. RFID technology for automation of library visit data as a development of QRCode, with the advantage of the difficulty of duplicating RFID cards with integrated 
Internet Of Things (IoT) with practical data storage. Another study from [10] the application of Radio Frequency Identification (RFID) technology to improve library services. The problem with libraries in general is that the library services provided are not optimal and the performance of human resources in the library. With RFID, users perform self-service in order to speed up the loan and return circulation process, so that the required time is efficient, which is complemented by training in using the system so that it can be used properly.

\section{METHODOLOGY}

\subsection{General System Overview}

This research method develops a library information system by applying an RFID-based NFC Card. The flow of this research begins by conducting a literature and literature study related to how the NFC card works, practicing making programs / coding on how to read and save data from and to NFC card. In addition, studying the flow of activities in the library in the form of loan and returning books for library data. The next stage is a system analysis to determine the language programming used, .Net C\# programming language, because this programming language is very compatible with integration with digital devices. To analyze the hardware requirements needed and design the database and system interface. The results of analysis and design are used as basis for system development, and system testing is carried out to find out whether the system can run properly. This research ends with the preparation of reports and publications. The flow of this research is described in Fig. 1

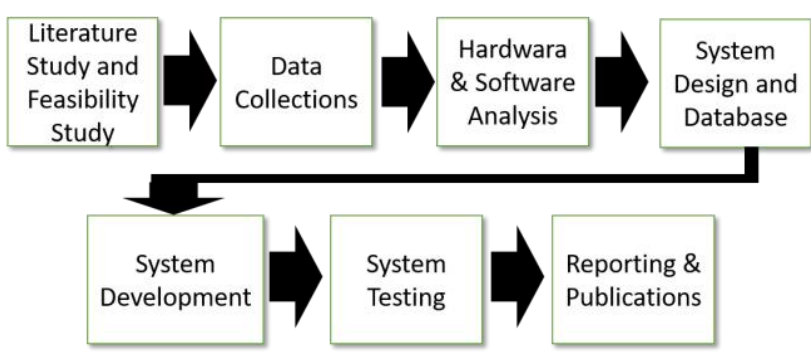

Fig 1: Research Flow

The data collection technique is carried out through direct observation and analyzing library data. At this stage, the system interface design is also carried out The system interface design consists of a library member master, a book master, a loan transaction books and book return transactions.

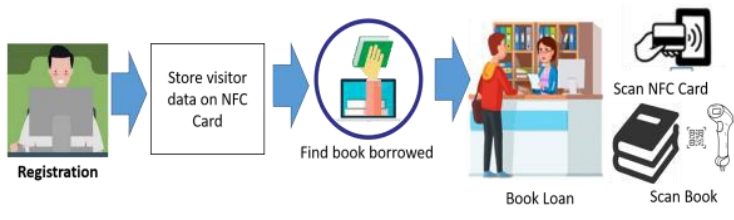

Fig 2: Book Loan Transaction

Fig 2 explains the flow of book loan starting from registering visitor, create a member card for new library member based on NFC Card. Next visitors enter the library to choose the books to be borrowed. Then the book is handed over to the librarian, scans the visitor's NFC card and then scan the QR Code label on each book. Data book loan has been stored on library management systems.

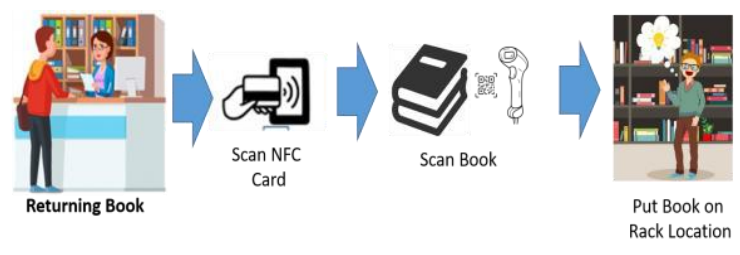

Fig 3: Book Return Transaction

Fig 3 describes the flow of returning library books. Once book returned, the librarian scans the borrower's /visitor card and scans books in the QR Code label. The returning book has been recorded in the system, the date of return and book Id, and returning date. Furthermore, after being returned, the books are rearranged on the rack by the librarian. Transaction data of book loan and book returning can be neatly recorded on the system which can later be recapitulated by print out the report.

\subsection{Context Diagram and Data Flow Diagram Design}

Design system implemented in context diagram and data flow diagram. Context diagram is shown in Fig 4.

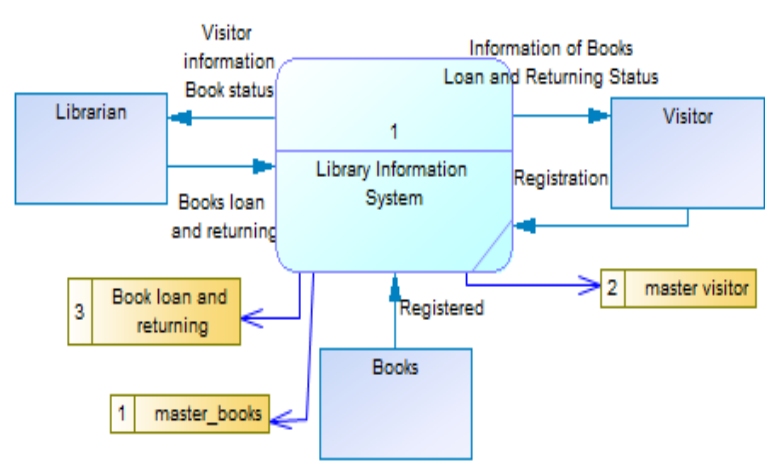

Fig 4: Context Diagram 
A context diagram is containing one process node that generalizes the function of the entire system in relationship to external entities. Context diagram above is composed of 3 external entities, 1 process, and 3 data stores. The entities are visitor, librarian and books. The arrow represents data flow into system or out from system, where each data flow is shown in the Fig. 4. Master books database is used to save books information and master visitor database is used to save all information of visitors' data, while book loan and returning database is used to store book loans transaction from visitor and books returning transaction by visitor.

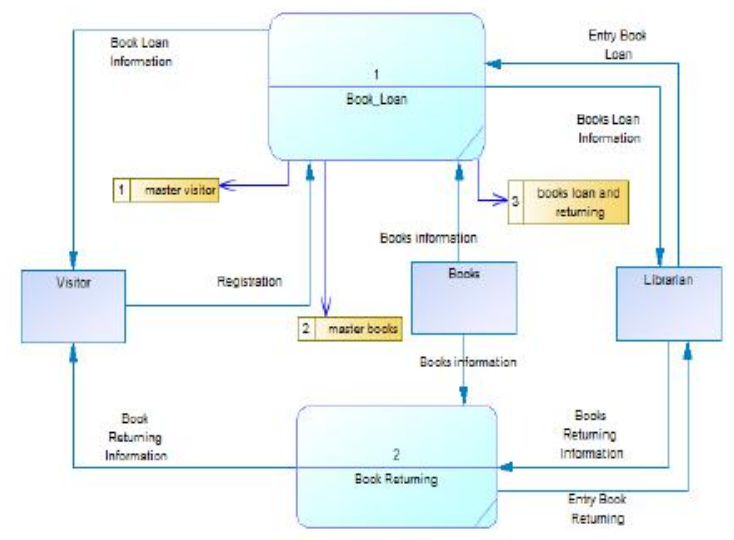

Fig 5: Data Flow Diagram Library Information System

Data flow diagram above shown process in context diagram is spitted into 2 process namely book loan and book returning. Book loan is used to manage all transaction of borrowing book by visitor, while book returning is used to manage all transaction of book returned by visitor, handled by librarian.

\section{RESULT AND DISCUSSION}

\subsection{Result}

Library Information System main menu consists of sub menu master visitor, master books, verification module, loan and returning books module and reporting module.

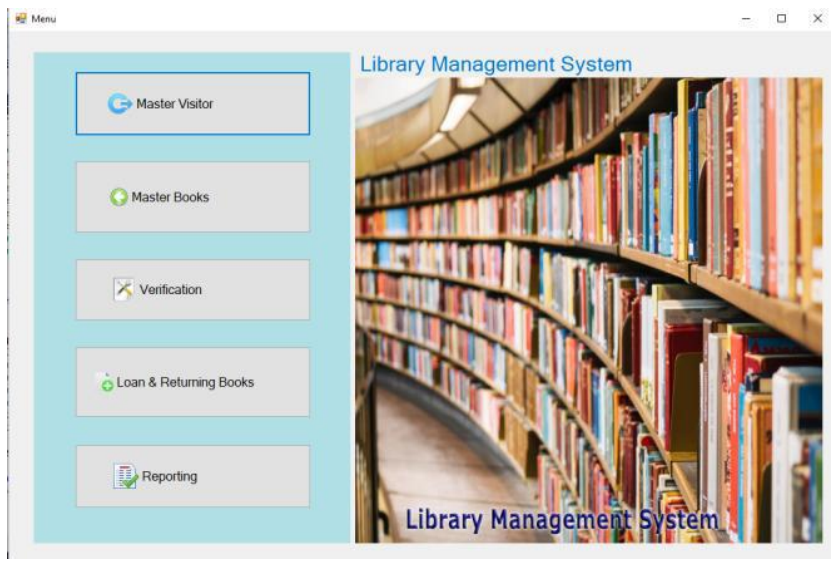

Fig 6: Main Menu User Interface

The master visitor user interface shows in Picture 7.

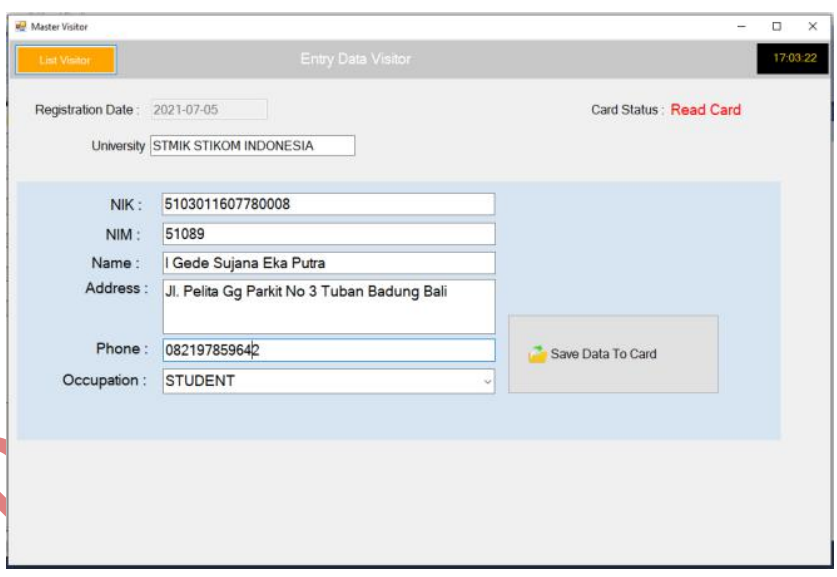

Fig 7: Master Visitor User Interface

Master data visitor is used to record visitor data, and then the visitor data stored in database and stored in RFID NFC Card.

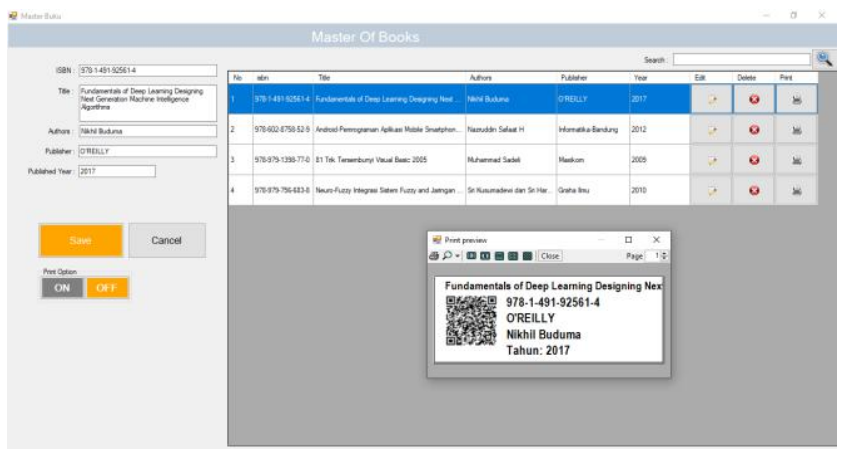

Fig 8: Master Books

Fig 8 shows master books module. Master books is used to store information of books. Each book could be put QR Code label printed from the system. 
Volume 9 Issue 8 August 2021

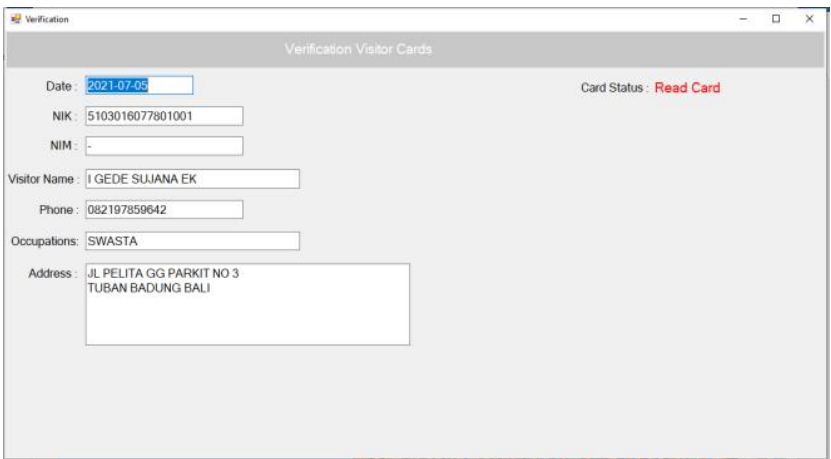

Fig 9: Verification Visitor Card

Fig 9 shows module for verification visitor card. This module is used to verify the visitor NFC Card, to make sure once the visitor data has been stored into the card.

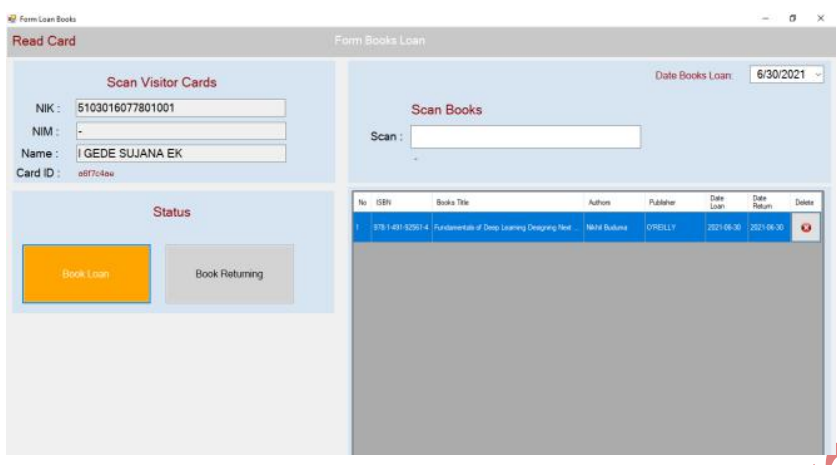

Fig 10: Books Loan Module

Fig 10 shows module for books loan. This module is used to loan books. The librarian tapped visitor NFC Card into NFC reader, and then scan each books label to record book loan into system. This is more practical and speed up to record data.

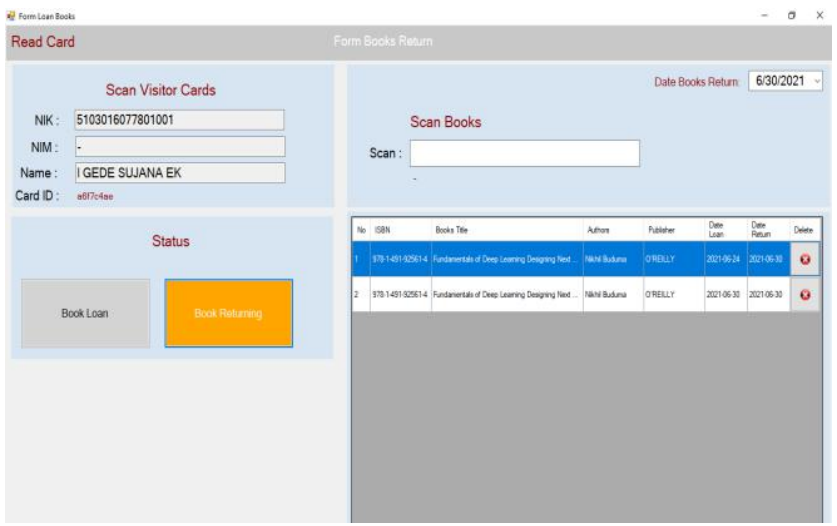

Fig 11: Books Return Module

Fig 11 shows module for books loan. This module is used to return books from visitor. Reporting module as shown in Fig 12 is used to generate report of loan and returning books, which has 3 parameter input. And Fig 13 shows example report of recapitulation of books loan and return. The report shows recapitulation data for book loan and return, help librarian to check each visitor loan and return transaction.

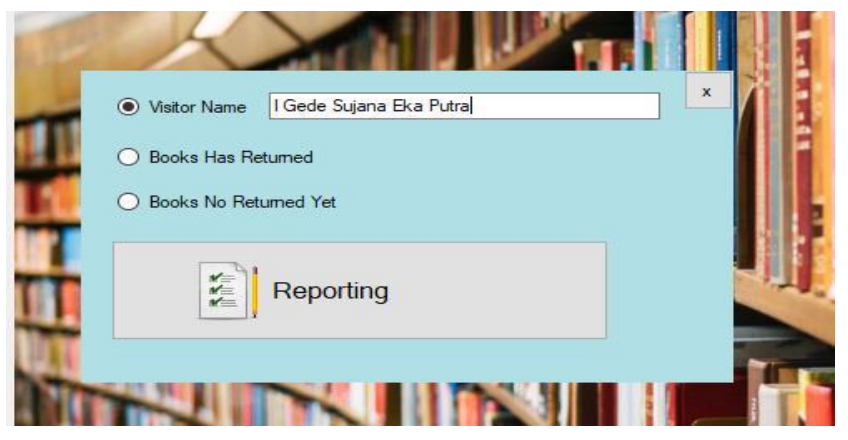

Fig 12: Report Loan and Returning Books

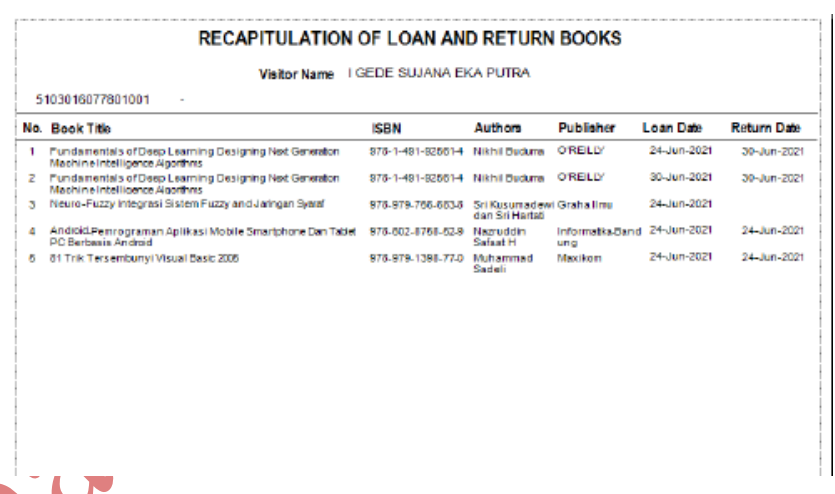

Fig 13: Example Report Recapitulation of Books Loan and Return

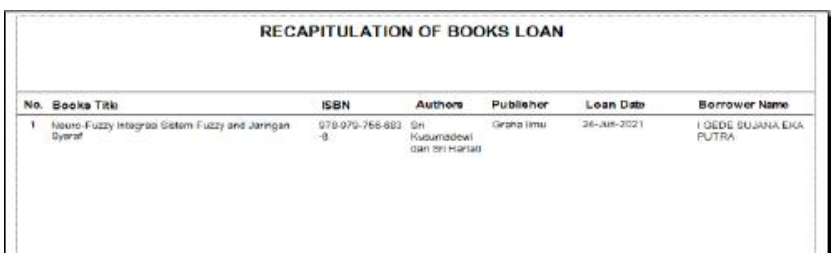

Fig 14: Example Report Recapitulation of Books Loan

Fig 14 shows example report of books loan. The report shows recapitulation all information data of book loan.

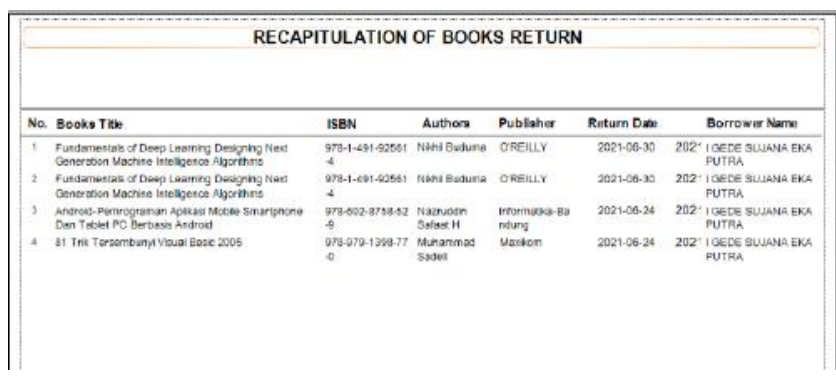

Fig 15: Example Report Recapitulation of Books Return 
Fig 15 shows example report of recapitulation of books return. The report shows recapitulation of all information regarding books return.

\subsection{Discussion}

Based on testing result, we found that NFC Card have sensitivity level to read /write data from NFC reader device. The testing results of the read/write NFC Card into NFC device are shown in Table 1.

Table 1. Testing Result of Tapping NFC Card Into NFC Device

\begin{tabular}{|c|c|c|c|}
\hline $\begin{array}{c}\text { Tapping } \\
\text { distance }(\mathbf{c m})\end{array}$ & Position & $\begin{array}{c}\text { Can Be } \\
\text { Read? }\end{array}$ & $\begin{array}{c}\text { Can Be } \\
\text { Write? }\end{array}$ \\
\hline $0 \mathrm{~cm}$ & $\begin{array}{c}\text { Stick to NFC } \\
\text { device }\end{array}$ & Yes & Yes \\
\hline $1 \mathrm{~cm}$ & Upright & Yes & Yes \\
\hline $2 \mathrm{~cm}$ & Upright & Yes & Yes \\
\hline $4 \mathrm{~cm}$ & Upright & Yes & Yes \\
\hline $7 \mathrm{~cm}$ & Upright & Yes & Yes \\
\hline $8 \mathrm{~cm}$ & Upright & No & No \\
\hline $1 \mathrm{~cm}$ & Sideway & No & No \\
\hline $7 \mathrm{~cm}$ & Sideway & No & No \\
\hline
\end{tabular}

Based on the test results from Table 1, it can be observed that the NFC Card could be $\mathrm{read} / \mathrm{write}$ at least at $7 \mathrm{~cm}$ distance from NFC reader/writer device in the upright position. While in the sideway position, NFC Card could not be read/write by NFC reader/writer.

Table 2. Testing Result of Scanning QR Code

\begin{tabular}{|c|c|c|}
\hline Label Position & $\begin{array}{c}\text { Scanning } \\
\text { Distance } \mathbf{( c m})\end{array}$ & Can Be Read? \\
\hline Flat & $10 \mathrm{~cm}$ & Yes \\
\hline Flat & $20 \mathrm{~cm}$ & Yes \\
\hline Flat & $40 \mathrm{~cm}$ & Yes \\
\hline Flat & $50 \mathrm{~cm}$ & No \\
\hline Folded & $10 \mathrm{~cm}$ & Yes \\
\hline Folded & $20 \mathrm{~cm}$ & Yes \\
\hline Folded & $40 \mathrm{~cm}$ & Yes \\
\hline Folded & $50 \mathrm{~cm}$ & No \\
\hline Flat & $10 \mathrm{~cm}$ & Yes \\
\hline Flat & $20 \mathrm{~cm}$ & Yes \\
\hline Flat & $40 \mathrm{~cm}$ & Yes \\
\hline
\end{tabular}

Based on the test results from Table 4 , it can be observed that the QR Code label could be read at maximum distance $40 \mathrm{~cm}$ in label position either in flat position or in folded position by using Xenon Honeywell QR Code scanner. This QR Code has high sensitivity to read QR Code label it also could read for folded label position.

\section{CONCLUSION}

The conclusion of this research is system design stages consist of direct observation, literature study, data collection, system analysis and hardware requirements, database and user interface design, system development, and system testing. Testing the system by tapping an NFC Card (RFID) on a NFC Card reader/writer, obtained the results of testing the maximum distance from the reading of the NFC Tag card is up to $7 \mathrm{~cm}$ can read NFC Card. While testing using QR Code label, it could be read at maximum distance $40 \mathrm{~cm}$ either in flat or folded label position. By using an RFID NFC Card and QR Code, it more practical in library management.

\section{REFERENCES}

[1] R. Habibi Muhammad and R. Satrio Adi, “Rancang Bangun Sistem Pengamanan Mobil Menggunakan ID Card Dengan Metode Radio Frequency Identification,” KOPERTIP Journal Ilmiah Manajemen Informatika dan Komputer., 2017, doi: 10.32485/kopertip.v1i1.10.

[2] M. Rifqi and N. Wardhani, "Aplikasi Peran Dan Kegunaan Teknologi Near Field Communication (Nfc) Terhadap Kegiatan Proses Belajar Mengajar Di Perguruan Tinggi," Jurnal Ilmu Teknologi dan Komputer, vol. 1, no. 1, pp. 20-26, 2017.

[3] Tirta Mahayana, I Gede Sujana Eka Putra, Anthony Lee and I. G. A. W. Dharmayasa, "Design and Development Of Lecturer Attendance System Using Radio Frequency Identification (RFID)," International Journal Computer Science Engineering., vol. 10, no. 1, [Online].

Available: http://www.ijcse.net/docs/IJCSE21-10-01010.pdf.

[4] M. P. Lukman and H. Angriani, "Implementasi Teknologi RFID Pada Sistem Antrian Rekam Medis Pasien di Rumah Sakit," Ilkom Jurnal Ilmiah., 2018 , doi: 10.33096/ilkom.v10i1.246.105-112. 
[5] Eko Budi Setiawan, Bobi Kurniawan, "Perancangan Sistem Absensi Kehadiran Perkuliahan Dengan Menggunakan Radio Frequency Identification (RFID)," vol. 1 No 2, 2015.

[6] J. Onibala, A. S. . Lumenta, and B. A. Sugiarso, "Perancangan Radio Frequency Identification (RFID) Untuk Sistem Absensi Berbasis Mikrokontroler ATmega 8535," EJournal Teknik Elektro dan Komputer, 2015.

[7] W. Wagino, M. E. Rosadi, and A. Wahyudi, "Aplikasi Perpustakaan Menggunakan SmartCard RFID (Radio Frequency Identification)," Technologia, vol. 8, no. 1, 2017, doi: 10.31602/tji.v8i1.717.

[8] A. Primadhasa, D. Triyanto, and Suhardi, "Sistem Manajemen Perpustakaan Menggunakan Radio Frequency Identification ( Rfid )," Coding, Sistem Komputer. Untan, vol. 05, no. 3, pp. 32-39, 2017.

[9] Rifki Maulana Insan and R. Rizal, "Penerapan Teknologi Radio Frequency Identification ( RFID ) Pada Data Kunjungan Perpustakaan," Journal of Informatics And Digital Expert, vol. 01, pp. 1-6, 2019.

[10] Sely Yoanda, "Peningkatan Layanan Perpustakaan Melalui Teknologi RFID," Jurnal Pustakawan Indonesia., vol. 16, no. 2, 2017.

[11]Hidajanto Djamal, "Radio Frequency Identification (RFID) Dan Aplikasinya," Jurnal Teknik Elektro, vol. 16, no. 1, pp. 4555, 2014. 